\title{
Quantifying forest net primary production: combining eddy flux, inventory and metabolic theory
}

\author{
Zheng-Hong $\operatorname{Tan}^{(1-2)}$, \\ Alice Hughes ${ }^{(2)}$, \\ Tamotsu Sato ${ }^{(3)}$, \\ Yi-Ping Zhang ${ }^{(2)}$, \\ Shi-Jie Han ${ }^{(4)}$, \\ Yoshiko Kosugi ${ }^{(5)}$, \\ Michael Goulden' ${ }^{(6)}$, \\ Xiao-Bao Deng ${ }^{(2)}$, \\ Min $\mathrm{CaO}^{(2)}$, \\ Zhan-Qing Hao ${ }^{(4)}$, \\ Yue-Hua Hu${ }^{(2)}$, \\ Gui-Rui Yu ${ }^{(7)}$ \\ Ke-Ping Ma ${ }^{(8)}$
}

\section{Introduction}

The earth's surface environment changed dramatically between 1960s and 2010s, in cluding changes in atmospheric gas concentrations, temperatures, and land-cover Notably, the surface temperature in creased by $0.9{ }^{\circ} \mathrm{C}$ and the atmospheric $\mathrm{CO}_{2}$ levels increased by 23\% (from 316 to 389 part per million - Brohan et al. 2006). The surface warming was most likely caused by radiative forcing resulting from atmospher ic $\mathrm{CO}_{2}$ buildup. Consequently, understand ing the carbon balance of ecosystems is a critical component in global change stud ies.

Net primary production $\left(N_{\mathrm{PP}}\right)$ is a centra carbon-related term which integrates climatic, ecological, geochemical and human

\begin{abstract}
Net primary production $\left(N_{\mathrm{PP}}\right)$ is a central and fundamental carbon-related term in global change studies. We proposed a top-down method to quantifying for est $N_{\mathrm{pp}}$ which overcomes the deficits of the traditional bottom-up method. The new top-down method combines eddy flux data, climate variables, tree inventory and metabolic theory. Our method was tested in six forests and provides reliable annual $N_{\mathrm{Pp}}$ estimations which are consistent with bottom-up results. Carbon use efficiency also supports this new method. Taking advantage of fine temporal resolution of our top-down method, we examined whether and confirmed $N_{p p}$ was well correlated with leaf area index at a seasonal scale, as suggested by past studies. The potential value of our new method as a standard $N_{p p}$ method is high because of the world-wide network on eddy tower and inventory plot, however further data of performance of the new method is needed to fully evaluate its performance under different conditions.
\end{abstract}

Keywords: Carbon Use Efficiency, Metabolic Theory of Ecology, Autotrophic Respiration, Biomass, Eddy Covariance

influences on the biosphere (Nemani et al. 2003). $N_{\mathrm{pp}}$ is the rate of biomass change in plants, including woody, leaf and root tissues, but also root exudates and volatile organic carbon compounds.

$N_{p p}$ is defined as the difference between gross primary production $\left(G_{\mathrm{PP}}\right)$ and total plant respiration $\left(R_{\mathrm{a}}\right)$ in an ecosystem (Schulze 2006). In the past, directly measuring both $G_{\mathrm{pp}}$ and $R_{\mathrm{a}}$ were impractical due to methodological constraints, especially for tall forest $G_{\mathrm{pp}}$ (Clark et al. 2001a). Whole ecosystem $R_{a}$ was not only difficult to estimate but also involved significant uncertainties (Lavigne 1997). Due to methodological advances, it is now possible to obtain ecosystem $G_{\mathrm{pp}}$ by using eddy-covariance techniques (Beer et al. 2010). Furthermore,

$\square$ (1) Ecology Program, Department of Environmental Science, Hainan University, Haikou 570228 (China); (2) Xishuangbanna Tropical Botanical Garden, Chinese Academy of Sciences, Kunming 650223 (China); (3) Department of Forest Vegetation, Forestry and Forest Products Research Institute, Tsukuba 305-8687 (Japan); (4) Institute of Applied Ecology, Chinese Academy of Sciences, Shenyang 110016 (China); (5) Forest Hydrology Lab, Graduate School of Agriculture, Kyoto University, Kyoto 606-8502 (Japan); (6) Department of Earth System Science, University of California, Irvine 92697 (USA); (7) Institute of Geographic Science and Natural Resources Research, Chinese Academy of Sciences, Beijing 100101 (China); (8) Institute of Botany, Chinese Academy of Sciences, Beijing 100093 (China)

@ Zheng-Hong Tan (tanzh@xtbg.ac.cn)

Received: Jul 01, 2016 - Accepted: Feb 13, 2017

Citation: Tan Z-H, Hughes A, Sato T, Zhang Y-P, Han S-J, Kosugi Y, Goulden M, Deng X-B, Cao M, Hao Z-Q, Hu Y-H, Yu G-R, Ma K-P (2017). Quantifying forest net primary production: combining eddy flux, inventory and metabolic theory. iForest 10: 475-482. - doi: 10.3832/ifor2159-010 [online 2017-04-12]

Communicated by: Silvano Fares

a potential way for reliable $R_{a}$ estimation has been developed based upon metabolic theory (Mori et al. 2010).

The traditional method to quantify $N_{\mathrm{PP}}$ was developed during International Biosphere Program (IBP - Newbould 1967), which calculate $N_{\mathrm{Pp}}$ by combining the organic tissue biomass growth of all quantifiable components within a plant or an area. Currently $N_{P P}$ is normally calculated using the IBP-method with field-surveys (Clark et al. 2001b).

Though widely-used, several intrinsic deficits exist in the IBP-method. First, not all $N_{\mathrm{pP}}$ components can be directly measured in the field due to environmental variations during the measuring interval (Clark et al. 2001a). Second, it is difficult to obtain a fine temporal resolution $N_{P p}$ (i.e., daily), and thus to explore the explicit links of $N_{\mathrm{PP}}$ to environmental conditions. Third, the IBP-Method is labor intensive and therefore difficult to implement automatically. Methodological constraints not only limit field-data availability, but also hinder the accuracy of $N_{\mathrm{pp}}$ estimation and prediction. Therefore, alternative new methods are urgently needed for forest $N_{\mathrm{PP}}$ studies.

We propose a new method to quantify $N_{\mathrm{PP}}$, which more accurately quantifies its various components and explores how these components co-vary with climatic variation at a high temporal resolution. The new method was tested in six primary forests. To overcome major deficits of the traditional IBP-method, we directly address weaknesses within the IBP method and compare the results derived from both methods. Top-down design, high temporal resolution, and automatic monitoring represent a significant advance in forest $N_{P P}$ 
estimation, and could provide a way of comparing $N_{P p}$ of forests globally. It could also serve as an independent way to verify estimation derived from the current IBPmethod.

\section{Materials and methods}

The new top-down method for $N_{P P}$

The new method estimates $N_{p p}$ via topdown analysis (eqn. 1):

$$
N_{p p}=G_{p p}-R_{a}
$$

The general work flow is illustrated in Fig. 1. Most data required by this method are derived from eddy flux, air temperature, and tree size. Tree size is converted into biomass by using allometric equations. $R_{a}$ of each tree at $20{ }^{\circ} \mathrm{C}\left(R_{20}\right)$ was estimated according to the common tree biomassrespiration relationship reported by Mori et al. (2010 - eqn. 2$)$ :

$$
\frac{1}{R_{20}}=\frac{1}{201.78 M^{1.408}}+\frac{1}{0.410 M^{0.805}}
$$

where $M$ is the biomass of a tree. The coefficients were estimated from 271 naturally growing trees in tropical, temperate and boreal forests, with a regression correlation coefficient of 0.99 (Mori et al. 2010). $R_{a}$ was constructed from the $Q_{10}$ model of Janssens \& Pilegaard (2003 - eqn. 3):

$$
R_{a}=R_{r e f}-Q_{10}^{\frac{\left(T-T_{r e f}\right)}{10}}
$$

where $R_{\text {ref }}$ is $R_{a}$ at the reference temperature $T_{\text {ref, }}$, here specified to $R_{20}$ at $20{ }^{\circ} \mathrm{C}$. $G_{p p}$ is obtained by partitioning eddy flux after necessary data treatment.

\section{Forests for testing}

Six forests were used to test the new method.

Forest 1: A temperate forest in Changbaishan (CBS), northeastern China. The geographic location is $128^{\circ} 28^{\prime} \mathrm{E}, 42^{\circ} 24^{\prime} \mathrm{N}$. The CBS forest is primary and over 250 years old with a canopy height of 26 meters. The annual mean temperature was $4{ }^{\circ} \mathrm{C}$ and the annual rainfall was $700 \mathrm{~mm}$. The dominant tree species are Pinus koraiensis, Tilia amurensis, Acer mono, Fraxinus mandshurica, and Quercus mongolica. Inventory data were collected from a 20 ha plot very close to the eddy flux site (Hao et al. 2008).

Forest 2: A tropical seasonal forest in $\mathrm{Xi}$ shuangbanna (BNS), Southwest China. The geographic location is $101^{\circ} 15^{\prime} \mathrm{E}, 21^{\circ} 55^{\prime} \mathrm{N}$. The annual mean temperature and rainfall were $21.7^{\circ} \mathrm{C}$ and $1490 \mathrm{~mm}$ respectively. The mean canopy height was $30 \mathrm{~m}$. Trees in the topmost layer primarily include Pometia tomentosa, Terminalia myriocarpa, Gironniera subaequalis, and Garuga floribunda. Inventory data were collected from a 1 ha plot beneath the eddy flux tower (Zhang et al. 2010).

Forest 3: A tropical seasonal deciduous forest in Mae Klong (MKL), Thailand. The geographic location is $108^{\circ} 53^{\prime} \mathrm{E}, 18^{\circ} 43^{\prime} \mathrm{N}$. The annual mean temperature and rainfall were $25^{\circ} \mathrm{C}$ and $1500 \mathrm{~mm}$ respectively. The mean canopy height was $30 \mathrm{~m}$. The stand age was around 30 years in 2008. Domestic species in overstory are Shorea siamensis, Vitex peduncularis, Xylia xylocarpa. Inventory data were collected from a 4 ha plot (Marod et al. 1999).

Forest 4: A tropical lowland rainforest in Pasoh (PSO), Malaysia. The geographic location of the forest is $102^{\circ} 18^{\prime} \mathrm{E}, 02^{\circ} 58^{\prime} \mathrm{N}$. The annual mean temperature and rainfall were $25.3^{\circ} \mathrm{C}$ and $1865 \mathrm{~mm}$ respectively. The mean canopy height was $35 \mathrm{~m}$. The studied forest is primary. Domestic species in overstory predominantly belong to Dipterocarpaceae, Leguminosae, Burseraceae. A total of 814 species existed in the 50 ha plot. Inventory data were collected from a 6 ha plot beneath the eddy flux tower (Hoshizaki et al. 2004, Kosugi et al. 2008).

Forest 5: A tropical secondary forest in Bukit Soeharto (BKS), Indonesia. The geographic location is $117^{\circ} 02^{\prime} \mathrm{E}, 0^{\circ} 51^{\prime} \mathrm{S}$. The annual mean temperature and rainfall were $27^{\circ} \mathrm{C}$ and $3300 \mathrm{~mm}$ respectively. The studied forest is a secondary forest. In 1998, the secondary-growth forest disappeared due to a forest fire facilitated by El Niño Southern Oscillation (ENSO) event. The mean canopy height was $12.4 \mathrm{~m}$ in year 2004. We used eddy flux data in 2001 and 2002 and tree census data in 2003. Domi- nant species in overstory were Macaranga gigantea. Inventory data were collected from three 1 ha plots which were not logged (Ruslim et al. 2000).

Forest 6: A logged tropical rainforest in Tapajos (K83), Brazil. The geographic location is $54^{\circ} 31^{\prime} \mathrm{E}, 03^{\circ} 01^{\prime} \mathrm{S}$. The annual mean temperature and rainfall were $25{ }^{\circ} \mathrm{C}$ and $1911 \mathrm{~mm}$ respectively. The mean canopy height was $35 \mathrm{~m}$. The inventory plot is 16 ha in the east of an eddy flux tower (Miller et al. 2004).

\section{The eddy flux based $G_{P P}$}

Eddy covariance based net ecosystem $\mathrm{CO}_{2}$ exchange $\left(\mathrm{N}_{\mathrm{EE}}\right)$ is estimated as (Monson \& Baldocchi 2014 - eqn. 4):

$$
N_{E E}=\rho \overline{w^{\prime} c^{\prime}}+\rho \int_{0}^{z} \frac{d c}{d t} d z
$$

The overbar indicates averaging over time, primes represent fluctuations from the average, $\rho$ is the molar density of dry air, $w$ is vertical wind velocity, $c$ is the mixing ratio of $\mathrm{CO}_{2}$ measured by infrared gas analyzer, $d c / d t$ is the change in $\mathrm{CO}_{2}$ mixing ratio with time, and $z_{r}$ is the measurement height.

The $N_{\mathrm{EE}}$ could be decomposed into $G_{\mathrm{PP}}$ and ecosystem respiration $\left(R_{\mathrm{e}}\right)$ as (eqn. 5):

$$
G_{P P}=-\left(N_{E E}-R_{e}\right)
$$

The minus sign outside the parenthesis results from discipline convention. Total $R_{e}$ is the sum of nighttime and daytime $R_{e}$, and conceptually nighttime $N_{\mathrm{EE}}$ is equivalent to nighttime $R_{e}$. However, nighttime $N_{E E}$ is usually underestimated during periods of low turbulence. The common way to correct this underestimation is the so-called $\mathrm{u}^{*}$ filtering method. In this method, the threshold $u^{*}$ was determined by finding a saturation point in $u^{*}$ and nighttime $N_{\mathrm{EE}}$ plot. All $N_{\mathrm{EE}}$ observations were filtered by removing all values below the $u^{*}$ threshold prior to analysis.

\section{Inventory, tree biomass, $R_{20}$ and $R_{a}$} estimation

Mori et al. (2010) suggests a common tree biomass-respiration relationship. $R_{20}$

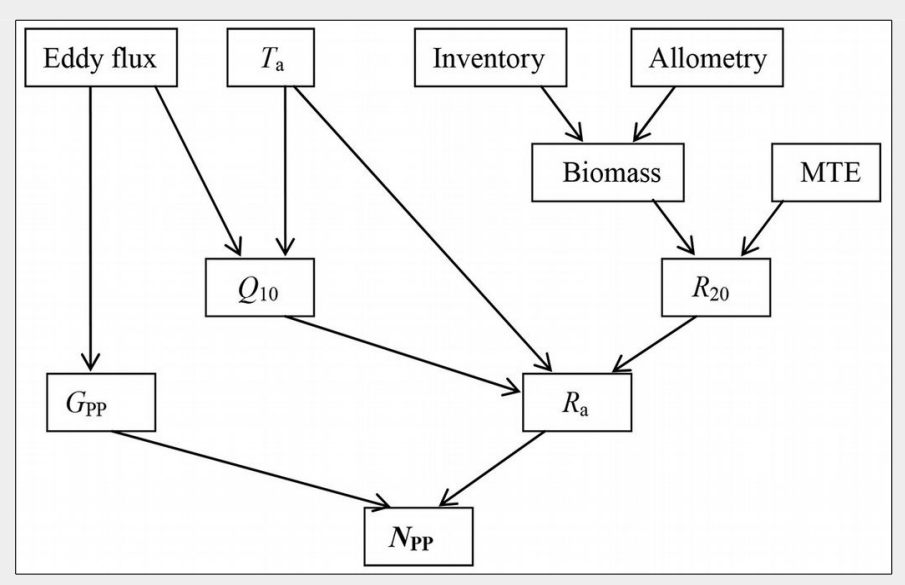

Fig. 1 - Flow schema of top-down estimation of forest net primary production $\left(\mathrm{N}_{\mathrm{PP}}\right)$. Eddy flux is carbon flux measured by eddy covariance technique; $\left(T_{\mathrm{a}}\right)$ : temperature; $\left(Q_{10}\right)$ : respiration temperature sensitivity index; $\left(G_{\mathrm{pP}}\right)$ : gross primary production; $\left(R_{20}\right)$ : tree autotrophic respiration at $20^{\circ} \mathrm{C} ;\left(R_{\mathrm{a}}\right)$ : autotrophic respiration; (MTE): metabolic theory of ecology here specified to Mori et al. (2010)'s work. Tree census (Inventory) data and sitespecific allometric equations were used in calculating tree biomass individually. 
was estimated from tree biomass obtained by Kato et al. (1978) for BKS, MKL and PSO; by Chen \& Guo (1984) for CBS; by Chambers et al. (2001) for K83; and by Lv et al. (2007) for BNS.

A mixed-power scaling rather than the single-power scaling of eqn. 2 was recommended by Mori et al. (2010). We compared $R_{20}$ estimated with both scaling. On the other hand, we used the $Q_{10}$ derived from flux tower $R_{\mathrm{e}}$, which includes the temperature sensitivity of both heterotrophic $\left(R_{\mathrm{h}}\right)$ and autotrophic respiration $\left(R_{\mathrm{a}}\right)$, to obtain $R_{a}$ with eqn. 3 . In some cases, the $Q_{10}$ of $R_{\mathrm{h}}$ and $R_{\mathrm{a}}$ is different and this might lead to biased estimate for $R_{a}$. Furthermore, we cannot obtain $Q_{10}$ value for an equatorial tropical rainforest where temperature range was very narrow. Under such circumstance, we used a fixed $Q_{10}$ of 2 for the equatorial rainforest (Amthor 1984, Slot et al. 2014). A sensitivity analysis was also used to investigate how $Q_{10}$ affect $R_{a}$.

\section{The IBP based NPP}

The detail on estimating $N_{P P}$ with IBP method has been extensively discussed in an IBP book (Newbould 1967) and a review by Clark et al. (2001a). In general, IBP based $N_{P P}$ was estimated as the sum of biomass increment and biomass losses occurred during the investigation interval both above- and below-ground. We did not estimate IBP based $N_{\mathrm{PP}}$ for each site but rather collected the published values.

\section{Other supporting measurements and calculations}

Remote sensing-derived leaf area index was generally used to estimate $N_{p P}$ at large scales (Gower et al. 1999, Ollinger et al. 2007). We calculated leaf area index $\left(L_{A I}\right)$ to examine whether it could explain the seasonal variation of evergreen tropical forest $N_{\mathrm{Pp}}$ at daily resolution.

Following Jarvis \& Leverenz (1983), $L_{A l}$ was estimated as (eqn. 6):

$$
L_{A I}=-\ln \left(\frac{Q_{T}}{Q_{0}}\right) / \kappa
$$

where $\kappa$ is extinction coefficient which varied between 0.4 and 0.65 . We used 0.55. $Q_{t}$ is the transmitted photosynthetically active radiation $\left(P_{\mathrm{AR}}\right)$, and was monitored by a sensor ( LI-19OSB $^{\oplus}$, LI-Cor, USA) placed at the height of $3.9 \mathrm{~m}$, and $Q_{0}$ is the $P_{A R}$ above the canopy measured by a sensor at the height of $36.2 \mathrm{~m}$.

\section{Results and discussion}

\section{The $R_{a}$ derived from metabolic theory} and its uncertainties

The application of Mori et al. (2010)'s finding in estimating forest $R_{a}$ is the key issue of this new method. Mori et al. (2010) claimed that a mixed-power function rather than a single-power function is better in describing the biomass-respiration relationship. The mixed-power function implying a
Tab. 1 - Estimated biomass and reference respiration rate at $20{ }^{\circ} \mathrm{C}\left(R_{20}\right)$. (MAT): mean annual temperature; (MAP): mean annual precipitation.

\begin{tabular}{lccccc}
\hline \multirow{2}{*}{ Forest } & MAT & $\begin{array}{c}\text { MAP } \\
{[\mathrm{mm}]}\end{array}$ & $\left.\begin{array}{c}\text { Biomass } \\
{\left[{ }^{\circ} \mathrm{C} \text { dry matter ha }\right.}\end{array}{ }^{-1}\right]$ & \multicolumn{2}{c}{$\boldsymbol{R}_{\mathbf{2 0}}\left[\boldsymbol{\mu m o l ~ \mathrm { m } ^ { - 2 } \mathbf { s } ^ { - 1 } ]}\right.$} \\
\hline Forest1: CBS & 4 & 700 & 291 & Single power & Mixed power \\
Forest2: BNS & 21.7 & 1490 & 375 & 3.437 & 3.067 \\
Forest3: MKL & 25 & 1500 & 265 & 2.998 & 3.545 \\
Forest4: PSO & 25.3 & 1865 & 456 & 4.872 & 2.090 \\
Forest5: BKS & 27 & 3300 & 239 & 2.532 & 2.317 \\
Forest6: K83 & 25 & 1911 & 348 & 4.091 & 3.660 \\
\hline
\end{tabular}

gradual ontogenetic transition in the scaling of metabolism is theoretically sound. We compared $R_{20}$ obtained with mixedpower function to that with single-power one (Tab. 1). The single-power based $R_{20}$ is $13 \%$ higher that of mixed-power. In the statistic perspective, both single-power and mixed-power functions have a good ability at simulating $R_{20}$ with correlation coefficient as high as 0.99 (Mori et al. 2010). The $R_{20}$, however, is very sensitive to the choice of single- or mixed-power function.

Other than $R_{20}$, another important parameter which affects $R_{a}$ estimation is the $Q_{10}$ value. Currently, data for $Q_{10}$ of $R_{a}$ are scarce. As shown in the flow chart of this new method (Fig. 1), we used $Q_{10}$ of $R_{e}$ derived from eddy flux observations. However, neither $R_{e}$ nor soil respiration $Q_{10}$ of equatorial tropical forest is available partly due to narrow temperature ranges. Some studies even found a negative or quadratic relationship between soil respiration and temperature (Hanpattanakit et al. 2015). Furthermore, $R_{e}$ is the sum of autotrophic $\left(R_{\mathrm{a}}\right)$ and heterotrophic components $\left(R_{\mathrm{h}}\right)$. The $Q_{10}$ derived from flux tower $R_{e}$, which includes the temperature sensitivity of both $R_{\mathrm{a}}$ and $R_{\mathrm{h}}$, might induce some bias when $Q_{10}$ of $R_{a}$ and $R_{h}$ is not the same.

Concerning $Q_{10}$, we analyzed the sensitivity of $Q_{10}$ with $R_{a}$ (Fig. 2). When the $Q_{10}$ value varied from 1.4 to $2.5, R_{a}$ changed slightly for sites which have mean annual tempera-

tures near $20^{\circ} \mathrm{C}$, (i.e., BNS - Fig. 2). However, these changes could be up to around $40 \%$ for other sites (Fig. 2). This means the $Q_{10}$ sensitivity is a critical issue in the new method. The $Q_{10}$ value for $R_{\mathrm{e}}$ is available for CBS and BNS sites and it was used to drive the new method. For the other five tropical forests where $Q_{10}$ is not available, it was set as 2.0 (Amthor 1984, Slot et al. 2014) and the corresponding $R_{a}$ estimates are shown in Tab. 2.

The third relevant issue which may induce additional uncertainties is the use of temperature response function to evaluate $R_{\mathrm{a}}$. Several alternative functions are available for this case (Gomez-Casanovas et al. 2013). For example, the highly cited Lloyd \& Taylor (1994)'s function as (eqn. 7):

$$
R_{a}=R_{r e f} \cdot \exp \left[E_{0}\left(\frac{1}{T_{r e f}-T_{0}}-\frac{1}{T-T_{0}}\right)\right]
$$

where $E_{0}$ and $T_{0}$ are two parameters which could be related to $Q_{10}$ as (eqn. 8):

$$
Q_{10}=\exp \left[\frac{10 E_{0}}{\left(T-T_{0}\right)\left(T+10-T_{0}\right)}\right]
$$

Similar to this, the classic Arrhenius function could be related to $Q_{10}$ as (eqn. 9):

$$
Q_{10}=\exp \left[\frac{10 E_{a}}{R T(T+10)}\right]
$$

where $E_{a}$ is the activation energy. We com-

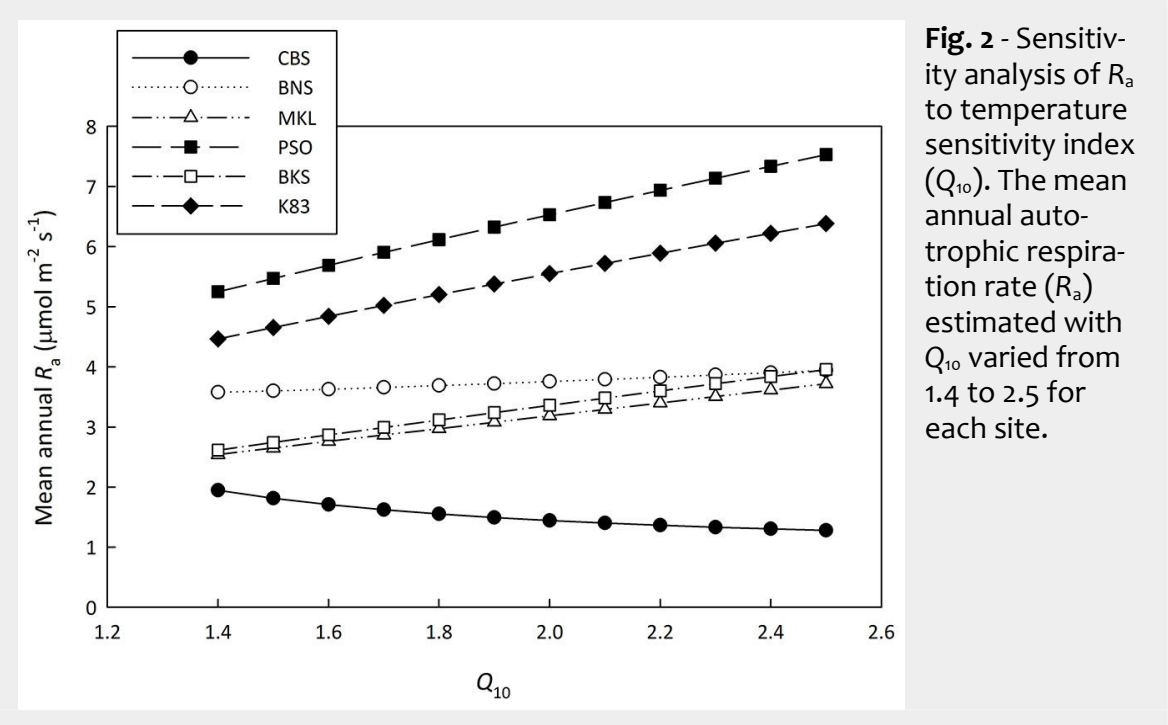


Tab. 2 - A summary table for eddy flux based gross primary production (GPP), IBP based net primary production (IBP- $N_{\mathrm{PP}}$ ), metabolic theory based autotrophic respiration $\left(R_{\mathrm{a}}\right)$ and the new top-down method based $N_{\mathrm{PP}}\left(\mathrm{New}-\mathrm{N}_{\mathrm{PP}}\right)$. All values are in the unit of $t C$ ha ${ }^{-1} \mathrm{yr} \mathrm{r}^{-1}$. $(\ddagger)$ : For CBS and BNS, $Q_{10}$ was derived from eddy flux based $R_{e}$, for other forests $Q_{10}$ was set at 2.0; ( () : values in parentheses represent the range from estimates when $Q_{10}=1.4$ to $Q_{10}=2.5 ;(£)$ : values after " \pm " in this column are $20 \%$ uncertainties, as suggested by Desai et al. (2008); other values after " \pm " in this table are standard deviations (STD); (1) Chen et al. (2013); (2) Zhang et al. (2010); (3) Dlioksumpun et al. (2009); (4) Kosugi et al. (2008); (5) Hirata et al. (2008); (6) Malhi et al. (2009); (7) Wang et al. (2006); (8) Zhang et al. (2010); (9) Kira (1978); (10) Toma et al. (2000)

\begin{tabular}{|c|c|c|c|c|}
\hline Forest & Eddy flux $G_{\mathrm{PP}}$ & IBP-N $N_{\mathrm{PP}}$ & $R_{\mathrm{a}}^{\ddagger}$ & New- $N_{P P}{ }^{\varepsilon}$ \\
\hline Forest1: CBS & $13.38^{(1)}$ & $7.69^{(7)}$ & $5.32 \pm 0.31$ & $8.06 \pm 1.61$ \\
\hline Forest2: BNS & $23.42 \pm 1.74^{(2)}$ & $8.80^{(8)}$ & $14.63 \pm 0.86$ & $8.79 \pm 1.75$ \\
\hline Forest3: MKL & $23.98^{(3)}$ & $7.97^{(3)}$ & $12.06(9.60 \sim 14.08)^{5}$ & $11.92 \pm 2.38$ \\
\hline Forest4: PSO & $32.16 \pm 1.32^{(4)}$ & $12.85^{(9)}$ & $24.72(19.87 \sim 28.50)$ & $7.44 \pm 1.48$ \\
\hline Forest5: BKS & $27.10^{(5)}$ & $14.70^{(10)}$ & $12.71(9.87 \sim 14.97)$ & $14.39 \pm 2.87$ \\
\hline Forest6: K83 & $31.40^{(6)}$ & $14.40 \pm 1.30^{(6)}$ & $21.00(16.90 \sim 24.15)$ & $10.40 \pm 2.08$ \\
\hline Mean \pm STD & $25.24 \pm 6.85$ & $11.07 \pm 3.27$ & $15.07 \pm 6.90$ & $10.17 \pm 2.64$ \\
\hline
\end{tabular}

pared the application of Lloyd \& Taylor (1994)'s function to the $Q_{10}$ function of eqn. 3 with the dataset in CBS site. The uncertainty caused by this difference is small. To simplify the methodology, we eventually used eqn. 3 for all cases in this study.

Eddy flux based $G_{p p}$ and its uncertainties One crucial component of the new top- down method is reliably calculating $G_{\mathrm{pP}}$ with eddy covariance based carbon fluxes (Fig. 1). The $G_{p p}$ can be obtained by decomposing $N_{\mathrm{EE}}$ as shown in eqn. 5. Extrapolating the post $u^{*}$ filtering nighttime $R_{\mathrm{e}}$ to that of daytime is a common method within the flux community (Reichstein et al. 2005). It has successfully been used to reproduce global $G_{\mathrm{pp}}$ (Beer et al. 2010).

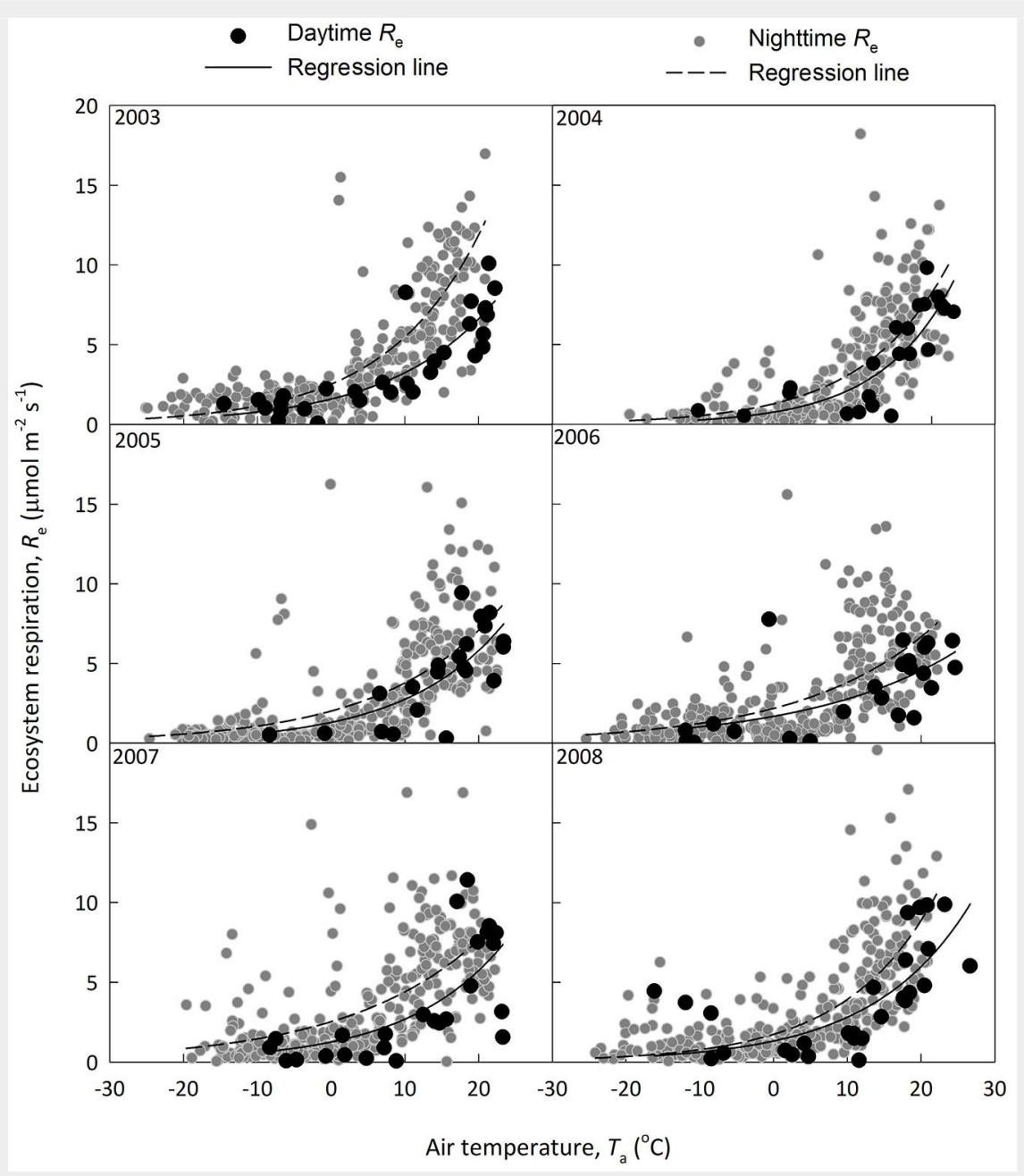

Fig. 3 - A comparison on daytime ecosystem respiration $\left(R_{e}\right.$, black circles and solid regression line) derived from light response and nighttime $R_{\mathrm{e}}$ (dark grey circles with dashed line). The $Q_{10}$ model (see text for detail) was used in fitting the dataset.
Nevertheless, the Reichstein et al. (2005) method was criticized for not providing a reliable $G_{\text {pp }}$ value. Leaf respiration may be inhibited under light conditions. Using values extrapolated from nighttime, but rather that of daytime, overestimates $R_{e}$ and subsequently the $G_{\mathrm{PP}}$ (Wohlfahrt et al. 2005a, Wehr et al. 2016).

As an alternative method, daytime respiration could be also obtained by extending daytime measurements to zero light, commonly termed as light response method (Wohlfahrt et al. 2005b, Lasslop et al. 2010). Rather than an extensive discussion and comparison on decomposition techniques separating $N_{\mathrm{EE}}$ into $G_{\mathrm{PP}}$ and $R_{\mathrm{e}}$, we used CBS site's data as a case analysis. The light response regression was done with a window of 10 days by using the MichaelisMenten function as (eqn. 10):

$$
N_{E E}=-\left(\frac{\alpha P_{m} I}{\alpha I+P_{m}}-R_{d}\right)
$$

where $I$ is the light intensity, $\alpha$ is the apparent quantum yield representing the slope under weak light, $P_{m}$ is the light-saturated photosynthesis rate, $R_{\mathrm{d}}$ is the derived daytime ecosystem respiration. The temperature dependence of $R_{\mathrm{d}}$ and nighttime $R_{\mathrm{e}}$ of CBS site is shown in Fig. 3. Nighttime $R_{e}$ was generally higher than that of daytime $R_{e}$ derived from light response. The $R_{e}$ estimation was compared between that derived from nighttime data only and that based on both day- and nighttime data (Fig. 4). This supports the claim that $R_{e}$ with nighttime flux was overestimated (Wehr et al. 2016), though the methods include some difficulties to quantify components.

(i) Can $R_{d}$ accurately represent the daytime ecosystem respiration? $R_{d}$ estimate is very sensitive to weak light observations. Weak light intensity usually occurs under transitional periods in the early morning, late afternoon or in periods of high cloud cover. Rapid and large changes in atmospheric stability will cause unnecessary uncertainties in this process, i.e., the flux burst effect in the morning (Grace et al. 1996). 
(ii) Could $R_{\mathrm{d}}$ derived from the simple light response model represent the daytime ecosystem respiration in reality? A group of variables drive daytime fluxes including $R_{\mathrm{d}}$. Lasslop et al. (2010), for example, showed that a model water vapor pressure deficit (VPD) included could work better in obtaining $R_{\mathrm{e}}$ and $G_{\mathrm{pP}}$ than a model drive by temperature only.

Uncertainties along with decomposition techniques in deriving $G_{\mathrm{pp}}$ are substantial. Desai et al. (2008) compared 23 decomposition methods and reported that most methods differed up to $20 \%$ in estimates of both $G_{p p}$ and $R_{\mathrm{e}}$ (see also Reichstein et al. 2005, Wohlfahrt et al. 2005b, Desai et al. 2008, Lasslop et al. 2010, Reichstein et al. 2012).

In this study, we cite published $G_{\mathrm{pp}}$ values for each site (Tab. 2) as a defensible, persuasive and unified decomposition technique on eddy flux based $G_{\mathrm{pp}}$ is currently unavailable (Desai et al. 2008, Wehr et al. 2016). Eddy flux data processing usually needs further site-specific information. We also compare the reported $G_{p p}$ to that obtained with an online processing procedure (http://www.bgc-jena.mpg.de/bgi/ index.php/Services/REddyProcWeb) widely used in European Flux communities for CBS and BNS, both of which show high levels of agreement. Thus, the up-to-date $G_{\mathrm{pp}}$ reported by site's investigators could be viewed as a good option.

\section{The matching of inventory plot with eddy flux footprint}

To apply the proposed method, we should ensure that the plot used for the inventory is comparable with the eddy covariance flux footprint for that site. Nevertheless, the scale of inventory plot and eddy flux footprint is usually not well matched both in space and time. While an inventory plot is usually set in a few hectares, an eddy flux footprint could be as large as $\sim 1 \mathrm{~km}^{2}$. In the current study, we selected six forests to validate the proposed method. The inventory plots of CBS, BNS, and PSO sites were just located within the eddy flux footprint. For the K83 site, inventory and eddy flux data have already been used in a matching method to address carbon balance (Miller et al. 2004). The forest type and disturbance history were the same in the inventory plot and eddy footprint for all six sites.

Another helpful experimental design is setting multiple small plots instead of a big one. Multiple small plots distributed in the footprint, when all footprint biomass estimation is not affordable, are definitely better in terms of representativeness than a single big one placed somewhere in the vicinity (Law et al. 2008). This helpful design was not involved in the current study but was strongly recommended for future studies.

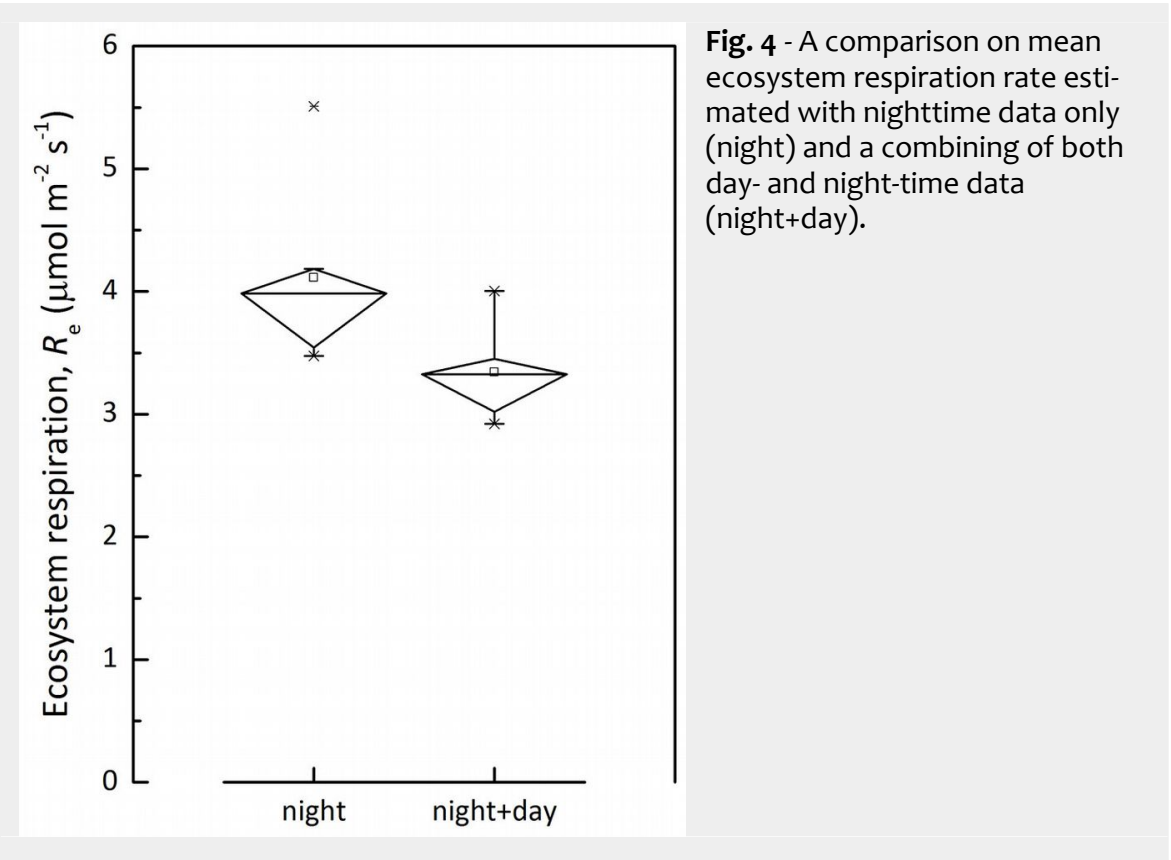

Comparison on the new top-down $N_{P P}$ and IBP based $N_{P P}$

Both the new top-down $N_{\mathrm{Pp}}$ and the IBP based $N_{P P}$ estimates are listed in Tab. 2, and a paired Student $t$-test showed no significant difference ( $p=0.55$ - Fig. 5). We also found $N_{P P}$ estimates are nearly identical for the CBS and BNS sites where $Q_{10}$ is available, providing strong support for the new top-down method.

Nevertheless, the new $N_{P p}$ differed from the IBP $N_{\mathrm{PP}}$ in the MKL, PSO and K83 sites. For the PSO and $\mathrm{K} 83$ sites, the new $N_{P P}$ seems to be underestimated whilst $R_{a}$ overestimated. This underestimation may be related to the assumed fixed $Q_{10}$ value. Conversely the MKL site shows the opposite, and the biomass of the MKL site is as low as that of the temperate CBS forest.

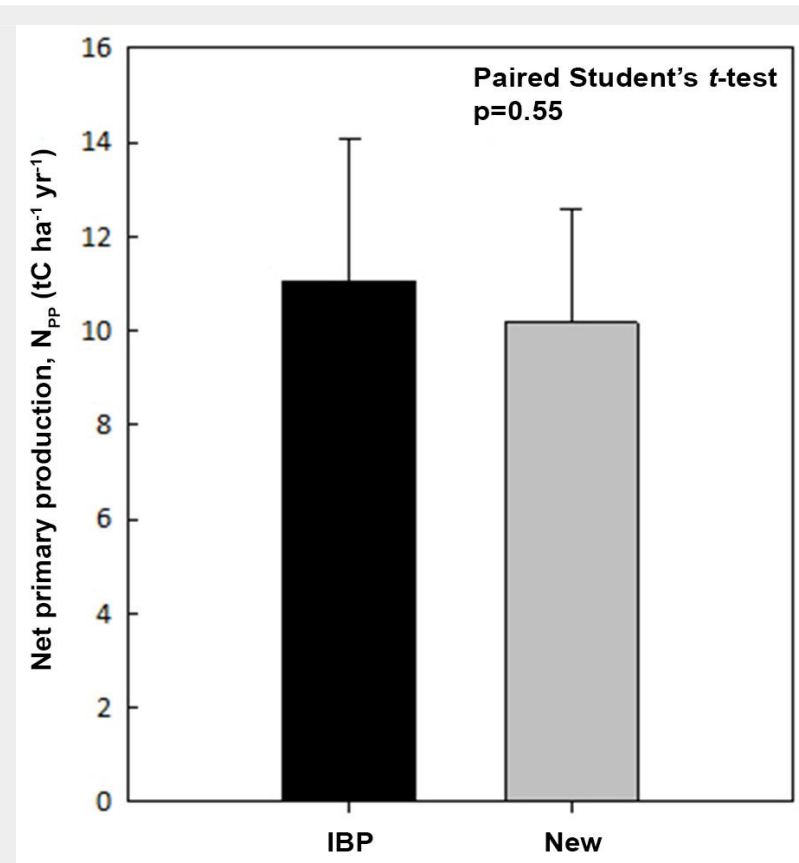

The MKL forest is under its secondary growth. The stand age of this secondary forest is only around 38 years and the inventory data used to calculate biomass and $R_{\mathrm{a}}$ was collected in year 1992, when the stand age was only 14 . Since biomass is expected to increase during the early stages of secondary growth, the biomass and $R_{\mathrm{a}}$ derived with data collected in 1992 is likely to be underestimated, which may account for the overestimation of $R_{a}$ with the new method in MKL.

Further support for the new top-down methods can be derived from the carbon use efficiency $\left(C_{\mathrm{UE}}\right)$, i.e., the ratio between $N_{\mathrm{PP}}$ and $G_{\mathrm{PP}}$. $C_{\mathrm{UE}}$ was reported to be about 0.50 in temperate forests (Waring et al. 1998, DeLucia et al. 2007, Zanotelli et al. 2013) and about 0.35 in tropical forests

Fig. 5 - A comparison on net primary production $\left(N_{\mathrm{PP}}\right)$ estimated with IBP method (IBP-NPP) and the new top-down method (New-NPP). 


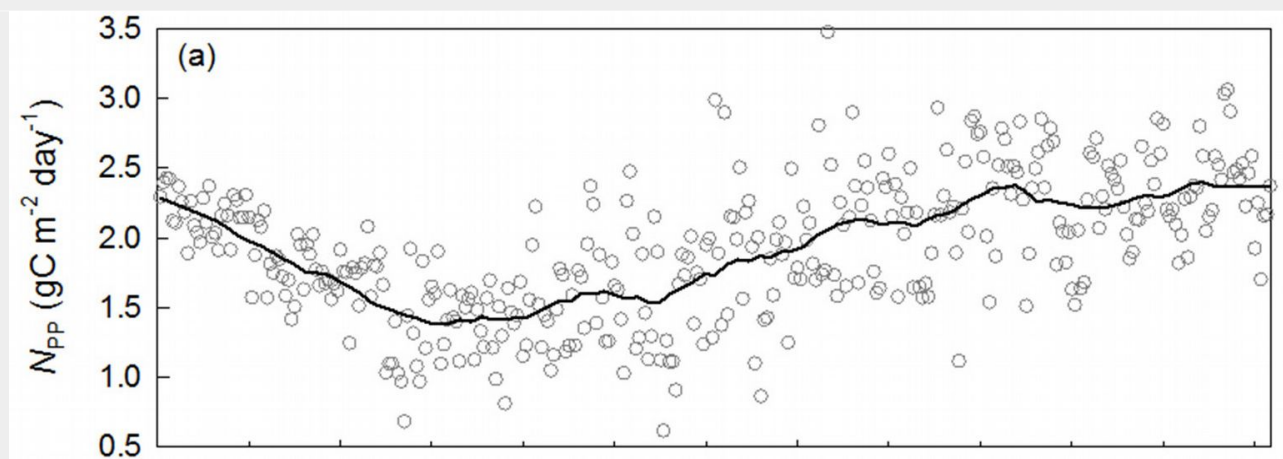

Fig. 6 - Seasonal variation of net primary production $\left(N_{\mathrm{PP}}\right)$ calculated by the proposed new method and leaf area index in a tropical rainforest of Xishuangbanna (BNS), China. (a): daily $N_{P P}$ in open circles in black grey, solid line show smoothing line; (b): daily leaf area index $\left(L_{\mathrm{Al}}\right)$ derived from light transmittance.

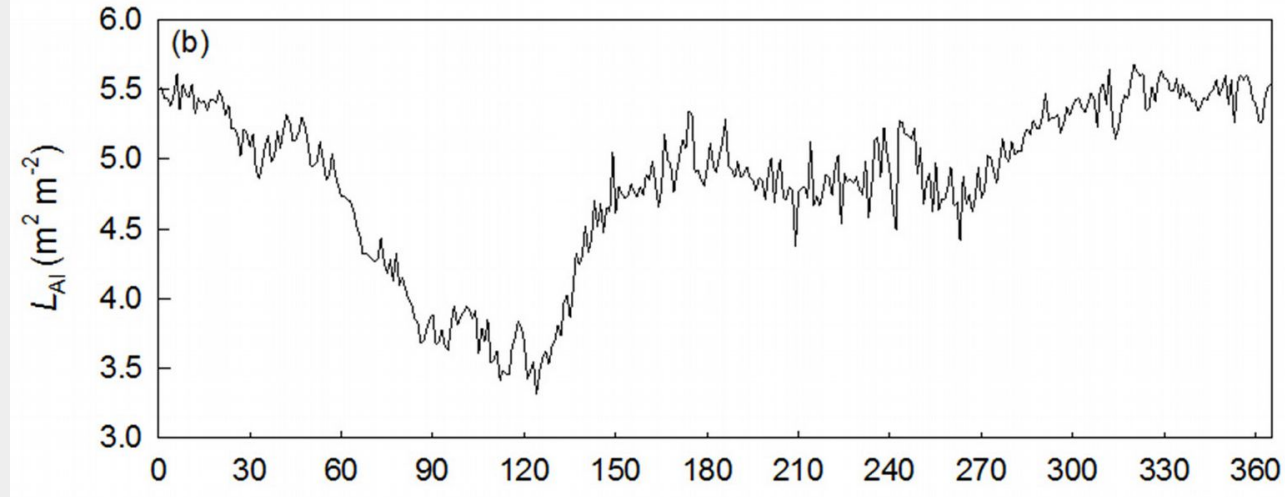

Day of Year, DOY

(Malhi 2012). $C_{\text {UE }}$ derived from the new topdown method was 0.60 in temperate forest and around 0.3 for primary tropical forests ( $C_{U E}$ is $0.37,0.23,0.33$ for BNS, PSO, $\mathrm{K} 83$, respectively), which agree well with the previous suggestions.

\section{The seasonal variation of $N_{P P}$}

Accurately quantifying the seasonal variation of forest $N_{\mathrm{Pp}}$ by the IBP method is challenging. The tradition temporal resolution for IBP based $N_{P P}$ is a year (Clark et al. 2001a), which ignores temporal variability in climatically variable sites. Most of our knowledge of $N_{P p}$ seasonality is indirectly obtained through remote sensing (Gower et al. 1999, Ollinger et al. 2007). The remote sensing inversion of $N_{\mathrm{Pp}}$ is based on the strong relationship between $N_{p p}$ and the vegetation index. We utilized the finest temporal resolution available for the topdown $N_{\mathrm{pp}}$ to test the relationship between the $N_{P P}$ and the vegetation index.

The seasonality in $N_{p P}$ is clear in BNS (Fig. $6 a$ ), and is lowest during the late dry season when water vapor pressure deficit $\left(V_{\mathrm{PD}}\right)$ and soil water deficit peak (indicated by soil water content, $S_{w c}$ ). The leaf area index $\left(L_{A 1}\right)$ was also lowest in the period. A close relationship was found between $L_{A 1}$ and $N_{P p}$ (Pearson's $r=0.56, n=365$ ). This result confirmed the reliability of remote sensing derived $N_{P P}$ and provides a direct estimate on seasonal $N_{\text {pp. }}$.

Currently, many forest sites have installed eddy covariance systems and established inventory plots. A world-wide test on this new top-down method will both advance our knowledge on $N_{P p}$ and give a more solid terrestrial $N_{P p}$ estimation. The limita- tions and uncertainties of the new topdown method are substantial. Incorporating other process based models into the top-down method would increase accuracy and may enhance its value as a standard method.

\section{Conclusions}

Forest $N_{p p}$ is a fundamental parameter describing the ecosystem functioning. It is the change rate of biomass including woody, leaf and woody tissues, exudates and volatile organic carbon compounds. We proposed a novel method to quantify $N_{\mathrm{Pp}}$ using measurements that are different from the traditional IBP method. We propose the use of eddy covariance together with the total biomass and the scaling factor proposed by Mori et al. (2010) to estimate the autotrophic respiration $\left(R_{a}\right)$. Then $N_{P P}$ is simply obtained from the gross primary production $\left(G_{\mathrm{pP}}\right)$ derived from eddy covariance, with the simple equation $N_{\mathrm{PP}}=$ $G_{\mathrm{PP}}-R_{\mathrm{a}}$.

Six sites were used to validate the proposed new method. They were selected because of the good match between inventory plot and eddy flux footprint. The new method provides reliable annual $N_{\mathrm{pp}}$ estimations which are consistent with bottomup results. This consistence was also supported by the past knowledge on carbon use efficiency. Taking the advantage of fine temporal resolution of the new top-down method, the seasonal changes of $N_{p p}$ at daily interval was presented. A close relationship between $N_{p p}$ and leaf area index was found at seasonal scale. This finding validated the new method on the one hand, and provided further support of using satellite vegetation index to address $N_{\mathrm{pp}}$ dynamics on the other. The potential of this new method as a standard $N_{\mathrm{pp}}$ method is high because of the world-wide network on eddy tower and inventory plot, however further work of using the method with cases under environmental stress is needed to fully evaluate its performance under variable conditions.

\section{Acknowledgements}

Eddy flux data sources include ChinaFLUX, AsiaFLUX, CForBio, website http:// www.ess.uci.edu/ lba/ and http://www.ff pri.affrc.go.jp/labs/EA-FDPN/. We would like to express thanks to the projects of "Long-term monitoring of forest carbon dynamics in East Asia [EA-FDPN Phase II]", ChinaFLUX, AsiaFLUX, CForBio and LBA for providing the data. The study was supported by National Natural Science Foundation of China (NSFC no. 31660142, 31200347), Youth Innovation Promotion Association of Chinese Academy of Sciences, and C-Project for talents of Hainan University.

\section{References}

Amthor JS (1984). The role of maintenance respiration in plant growth. Plant, Cell and Environment 7: 561-569. - doi: 10.1111/1365-3040.ep115 91833

Beer C, Reichstein M, Tomelleri E, Ciais P, Jung $M$, Carvalhais N, Rodenbeck C, Arain MA, Baldocchi DD, Bonan GB, Bondeau A, Cescatti $A$, Lasslop $G$, Lindroth $A$, Lomas $M$, Luyssaert $S$, Margolis $\mathrm{H}$, Oleson KW, Roupsard O, Veenendaal E, Viovy N, Williams C, Woodward Fl, Papale D (2010). Terrestrial gross carbon dioxide uptake: global distribution and covariation 
with climate. Science 329: 834-838. - doi: 10.1126/science. 1184984

Brohan P, Kennedy JJ, Haris I, Tett SFB, Jones PD (2006). Uncertainties estimates in regional and global observed temperature changes: a new dataset from 1850. Journal of Geophysical Research Atmosphere 111: D12106. - doi: 10.1029/20 05JD006548

Chambers JQ, Santos JD, Ribeiro RJ, Higuchi N (2001). Tree damage, allometric relationships, and above-ground net primary production in central Amazon forest. Forest Ecology and Management 152: 73-84. - doi: 10.1016/S03781127(00)00591-0

Chen CG, Guo XF (1984). Biomass of broadleaved red pine forest. Forest Investigation and Design 2: 10-19.

Chen Z, Yu G, Ge J, Sun X, Hirano T, Saigusa N, Wang Q, Zhu X, Zhang Y, Zhang J, Yan J, Wang H, Zhao L, Wen X, Shi P, Zhao F (2013). Temperature and precipitation control of the spatial variation of terrestrial ecosystem carbon exchange in the Asian region. Agricultural and Forest Meteorology 182-183: 266-276. - doi: 10.1016/j.agrformet.2013.04.026

Clark DA, Brown S, Kichlighter DW, Chambers JQ, Thomlinson JR, Ni J (2001a). Measuring net primary production in forests: concepts and field methods. Ecological Applications 11: 356370. - doi: 10.1890/1051-0761(2001)011[0356:MN PPIF]2.0.CO;2

Clark DA, Brown S, Kichlighter DW, Chambers JQ, Thomlinson JR, Ni J, Holland EA (2001b). Net primary production in tropical forests: an evaluation and synthesis of existing field data. Ecological Applications 11: 371-384. - doi: 10.189 o/1051-0761(2001)011[0371:NPPITF]2.0.CO;2

DeLucia E, Drake JE, Thomas RB, Melers MG (2007). Forest carbon use efficiency: is respiration a constant fraction of gross primary production? Global Change Biology 13: 1157-1167. doi: 10.1111/j.1365-2486.2007.01365.x

Desai AR, Richardson AD, Moffat AM, Kattge J, Hollinger DY, Barr A, Falge E, Noormets A, Papale D, Reichstein M, Stauch VJ (2008). Cross site evaluation of eddy covariance GPP and RE decomposition techniques. Agricultural and Forest Meteorology 148: 821-838. - doi: 10.1016/ j.agrformet.2007.11.012

Dlioksumpun S, Visaratana T, Panuthai S, Ladpala P, Janmahasatien S, Sumran S (2009). Carbon cycling in the Sakaerat dry evergreen and the Marklong mixed deciduous forests. Thailand Journal of Forestry 28: 67-81.

Gomez-Casanovas N, Anderson-Teixeira K, Zeri M, Bernacchi CJ, DeLucia EH (2013). Gap filling strategies and errors in estimating annual soil respiration. Global Change Biology 19: 19411952. - doi: 10.1111/gcb.12127

Gower ST, Kucharik CJ, Norman JM (1999). Direct and indirect estimation of leaf area index, fAPAR, and net primary production of terrestrial ecosystems. Remote Sensing of Environment 70: 29-51. - doi: 10.1016/So034-4257 (99)00056-5

Grace J, Malhi Y, Lloyd J, Mclntyre J, Miranda AC, Meir P, Miranda HS (1996). The use of eddy covariance to infer the net carbon dioxide uptake of Brazilian rain forest. Global Change Biology 2: 209-217. - doi: 10.1111/j.1365-2486.1996.tbooo7 $3 . x$
Hanpattanakit P, Leclerc MY, Mcmillan AMS, Limtong $\mathrm{P}$, Maeght JL, Panuthai S, Inubushi K, Chidthaisong A (2015). Multiple timescale variations and controls of soil respiration in tropical dry dipterocarp forest, western Thailand. Plant and Soil 390: 167-181. - doi: 10.1007/s11104-0152386-8

Hao ZQ, Li BH, Zhang J, Wang XG, Ye J, Yao XL (2008). Broad-leaved Korean pine (Pinus koraiensis) mixed forest plot in Changbaishan (CBS) of China: community composition and structure. Acta Phytoecologica Sinica 32 (2): 238250.

Hirata R, Saigusa N, Yamamoto S, Ohtani Y, Ide R, Asanuma J, Gamo M, Hirano T, Kondo H, Kosugi Y, Li SG, Nakai Y, Takagi K, Tani M, Wang $\mathrm{H}$ (2008). Spatial distribution of carbon balance in forest ecosystems across East Asia. Agricultural and Forest Meteorology 148: 761-775. doi: 10.1016/j.agrformet.2007.11.016

Hoshizaki K, Niiyama K, Kimura K, Yamashita T, Bekku Y, Okuda T, Quah ES, Noor NSM (2004). Temporal and spatial variation of forest biomass in relation to stand dynamics in a mature, lowland tropical rainforest, Malaysia. Ecological Research 19: 357-363. - doi: 10.1111/j.1440-1703. 2004.00645.x

Janssens IA, Pilegaard K (2003). Large seasonal changes in $\mathrm{Q}_{10}$ of soil respiration in a beech forest. Global Change Biology 9: 911-918. - doi: 10.1046/j.1365-2486.2003.00636.x

Jarvis PG, Leverenz JW (1983). Productivity of temperate, deciduous and evergreen forests. In: "Physiological Plant Ecology IV. Ecosystem processes: mineral cycling, productivity, and man's influence" (Lange OL, Nobel PS, Osmond CB, Ziegler H eds). Encyclopedia of Plant Physiology, Springer-Verlag, New York, USA, vol. 12D, pp. 233-28o. - doi: 10.1007/978-3-642-681561_9

Kato R, Tadaki Y, Ogawa H (1978). Plant biomass and growth increment studies in Pasoh Forest. Malaysian Nature Journal 30: 211-224.

Kira T (1978). Primary productivity of Pasoh forest - a synthesis. Malaysian Nature Journal 30: 291-297.

Kosugi Y, Takanashi S, Ohkubo S, Matsuo N, Tani M, Mitani T, Tsutsumi D, Abdul Rahim N (2008). $\mathrm{CO}_{2}$ exchange of a tropical rainforest at Pasoh in Peninsular Malaysia. Agricultural and Forest Meteorology 148: 439-452. - doi: 10.1016/j.agr formet.2007.10.007

Lasslop G, Reichstein M, Papale D, Richardson AD, Arneth A, Barr A, Stoy P, Wohlfahrt G (2010). Separation of net ecosystem exchange into assimilation and respiration using a light response curve approach: critical issues and global evaluation. Global Change Biology 16: 187-208. - doi: 10.1111/j.1365-2486.2009.02041.x

Law B, Arkebauer T, Campbell JL, Chen J, Sun O, Schwartz M, Van Ingen C, Verma SB (2008). Terrestrial carbon observations: protocol for vegetation sampling and data submission. TCO panel of the Global Terrestrial Observing System (GTOs-55), Global Terrestrial Observing System, Rome, Italy, pp. 4-8. [online] URL: http://www.fao.org/gtos/

Lavigne MB (1997). Comparing nocturnal eddy covariance measurements to estimates of ecosystem respiration made by scaling chamber measurements at six coniferous boreal sites. Journal of Geophysical Research Atmosphere 102: 28977-28985. - doi: 10.1029/97JD01 173

Lloyd J, Taylor J (1994). On the temperature dependence of soil respiration. Functional Ecology 8: 315-323. - doi: 10.2307/2389824

Lv XT, Tang JW, He YC, Duan WG, Song JP, Xu $H L$, Zhu SZ (2007). Biomass and its allocation in tropical seasonal rain forest in Xishuangbanna, Southwest China. Journal of Plant Ecology 31: 11-22. - doi: 10.17521/cjpe.2007.0003

Malhi Y (2012). The productivity, metabolism and carbon cycle of tropical forest vegetation. Journal of Ecology 100: 65-75. - doi: 10.1111/j.13652745.2011.01916.x

Malhi Y, Aragão LEOC, Metcalfe DB, Paiva R, Quesada CA, Almeida S, Anderson L, Brando P, Chambers JQ, Costa ACL, Hutyra LR, Oliveira P, Patino S, Pyle EH, Robertson AL, Teixeira LM (2009). Comprehensive assessment of carbon productivity, allocation and storage in three Amazonian forests. Global Change Biology 15: 1255-1274. - doi: 10.1111/j.1365-2486.2008.01780.x Marod D, Kutintara U, Yarwudhi C, Tanaka H, Nakashizuka T (1999). Structural dynamics of a natural mixed deciduous forest in Western Thailand. Journal of Vegetation Science 10: 777786. - doi: $10.2307 / 3237302$

Miller SD, Goulden ML, Menton MC, Da Rocha $H R$, Freitas $H C$, Figueira AMS, Sousa CAD (2004). Biometric and micrometeorological measurements of tropical forest carbon balance. Ecological Applications 14 (sp4): 114-126. doi: $10.1890 / 02-6005$

Monson R, Baldocchi DD (2014). Terrestrial biosphere-atmosphere interactions. Cambridge University Press, Cambridge, UK, pp. 339. [online] URL: http://books.google.com/books? id=nXLgAgAAQBAJ

Mori S, Yamaji K, Ishida A, Prokushkin SG, Masyagina OV, Hagihara A, Hoque A, Suwa R, Osawa A, Nishizono T (2010). Mixed-power scaling of whole-plant respiration from seedlings to giant trees. Proceedings of the National Academy of Sciences USA 107: 1447-1451. - doi: 10.1073/pnas.0902554107

Nemani RR, Keeling CD, Hashimoto $H$, Jolly $M$, Running SW, Piper SC, Tucker CJ, Myneni R (2003). Climate driven increases in terrestrial net primary production from 1982 to 1999 . Science 300: 1560-1563. - doi: 10.1126/science.108 2750

Newbould PJ (1967). Methods for estimating the primary production of forests. Blackwell Scientific Press, New York, USA, pp. 5-8. - [online] URL: http://citeseerx.ist.psu.edu/viewdoc/dow nload?doi=10.1.1.475.3375\&rep=rep1\&type=pdf Ollinger SV, Treuhaft RN, Braswell BH, Anderson JE, Martin ME, Smith ML (2007). The role of remote sensing in the study of terrestrial net primary production. In: "Principles and standards for measuring primary production" (Fahey TJ, Knapp AK eds). Oxford University Press, Oxford, UK, pp. 204-237. - doi: 10.1093/ acprof:oso/9780195168662.001.0001

Reichstein M, Falge E, Baldocchi D, Papale D, Aubinet M, Berbigier P (2005). On the separation of net ecosystem exchange into assimilation and ecosystem respiration: review and improved algorithm. Global Change Biology 11: 1424-1439. - doi: 10.1111/j.1365-2486.2005.00100 


$$
\text { 2.x }
$$

Reichstein M, Stoy PC, Desai AR, Lasslop D, Richardson AD (2012). Partioning of net fluxes. In: "Eddy covariance: a practical guide to measurement and data analysis" (Aubinet $M$, Vesala T, Papale D eds). Springer, New York, USA, pp. 263-289. - doi: 10.1007/978-94-0072351-1_9

Ruslim Y, Matius P, Sutisna M (2000). A case study of second felling in a logged-over dipterocarp forest. In: "Raiforest Ecosystems of East Kalimantan” (Guhardja E, Fatawi M, Sutisna M, Mori T, Ohta S eds). Springer, Tokyo, Japan, pp. 219-227. - doi: 10.1007/978-4-431-67911-0_19

Schulze ED (2006). Biological control of the terrestrial carbon sink. Biogeosciences 3: 147-166. doi: $10.5194 /$ bg-3-147-2006

Slot M, Rey-Sánchez C, Gerber S, Lichstein JW, Winter K, Kitajima K (2014). Thermal acclimation of leaf respiration to tropical trees and lianas: response to experimental canopy warming and consequences for tropical forest carbon balance. Global Change Biology 20: 29152926. - doi: 10.1111/gcb.12563
Toma T, Matius P, Hastaniah Kiyono Y, Watanabe R, Okimori $Y$ (2000). Dynamics of burned lowland Dipterocarp forest stands in Bukit Soeharto, East Kalimantan. In: "Rainforest Ecosystems of East Kalimantan: El Nino, Dorught, Fire and Human Impacts" (Guhardja E, Fatawi M, Sutisna M, Mori T, Ohta S eds). Springer Press, Tokyo, Japan, pp. 107-120. - doi: 10.1007/978-4431-67911-0_10

Wang M, Guan DX, Wang YS, Hao ZQ, Liu YQ (2006). Estimate of productivity in ecosystem of the broadleaved Korean pine mixed forest in Changbai Mountain. Science in China D 49: 7488. - doi: $10.1007 / \mathrm{s} 11430-006-8074-z$

Waring RH, Landsberg JJ, Williams M (1998). Net primary production of forests: a constant fraction of gross primary production? Tree Physiology 18: 129-134. - doi: 10.1093/treephys/18.2.129 Wehr R, Munger JW, McManus JB, Nelson DD, Zahniser MS, Davidson EA, Wofsy SC, Saleska SR (2016). Seasonality of temperate forest photosynthesis and daytime respiration. Nature 534: 680-683. - doi: 10.1038/nature17966 Wohlfahrt G, Bahn M, Haslwanter A, Newesely C,
Cermusca A (2005a). Estimation of daytime ecosystem respiration to determine gross primary production of a mountain meadow. Agricultural and Forest Meteorology 130: 13-25. doi: 10.1016/j.agrformet.2005.02.001

Wohlfahrt G, Anfang C, Bahn M, Haslwanter A, Newesely C, Schmitt M, Drosler M, Pfadenhauer J, Cernusca A (2005b). Quantifying nighttime ecosystem respiration of a meadow using eddy covariance, chambers and modeling. Agricultural and Forest Meteorology 128: 141-162. doi: 10.1016/j.agrformet.2004.11.003

Zanotelli D, Montagnani L, Manca G, Tagliavini M (2013). Net primary productivity, allocation pattern and carbon use efficiency in an apple orchard assessed by integrating eddy covariance, biometric and continuous soil chamber measurements. Biogeosciences 10: 3089-3108. doi: 10.5194/bg-10-3089-2013

Zhang Y, Tan Z, Song Q, Yu G, Sun X (2010). Respiration controls the unexpected seasonal pattern of carbon flux in an Asian tropical rain forest. Atmospheric Environment 44: 3886-3893. doi: 10.1016/j.atmosenv.2010.07.027 